\title{
Coccomyxa subellipsoidea, a new member of the Palmellaceae.
}

\author{
BY \\ ELIZABETH ACTON, B.SC. \\ University Scholar, Birmingham.
}

\section{With Plate XLIII.}

$\mathrm{T}$ HE Alga which forms the subject of this paper has long required thorough investigation. It is widely distributed in all parts of the British Islands, occurring only in subaerial habitats, generally on damp rocks and stones. It forms a thin mucous stratum of a dark green colour, which when dry becomes almost black and peels off the stone. The same Alga is not infrequently found in cold greenhouses, the green mucous stratum occurring both on the glass and woodwork, if sufficiently damp.

The stratum consists of large numbers of thin-walled cells embedded in a colourless mucilage. The cells are not all of precisely the same form, but for the most part they could be described as somewhat irregularly or obliquely ellipsoid. ${ }^{1}$ Among these ellipsoid cells are some in which the ends are more pointed, and others which are almost spherical. Sometimes one end of the cell is much more pointed than the other, especially after division has just taken place. The cells are $6-10 \mu$ in length by $4-6 \mu$ in breadth. Each cell has a thin inner cellulose wall and an outer gelatinous coat. The chloroplast is parietal, and of variable shape, seldom covering more than half the cell-wall (Pl. XLIII, Fig. I). It sometimes forms a U-shaped band and sometimes a shallow cup ; and the margin may be entire, undulated, or drawn out into fine processes, which occasionally meet across the central vacuole (Fig. I $a$ ). In unstained material no pyrenoid is visible, though in some specimens small refractive granules can be distinguished; but on treating with a solution of iodine in potassium iodide a single pyrenoid becomes visible in the centre of the chloroplast, while the refractive granules are seen to be starch granules.

1 The form of the cell evidently varies slightly under different conditions. In material collected three months later from the same place as that described above, the majority of the cells were nearly spherical.

[Annals of Botany, Vol. XXIII. No. XCII. October, 19og.] 
Multiplication takes place by oblique fission, the mother-cell dividing into two, or occasionally four daughter-cells, which are exactly similar to the parent cell (Fig. 2).

Reproduction takes place by the formation within the mother-cells of four, or rarely eight, non-motile gonidia, which are nearly spherical $2-4 \mu$ in diameter, and arranged either in the form of a tetrad or all in the same plane (Fig. 3). These may be formed in rapid succession, and as the gonidia do not at once separate, subspherical aggregates consisting of a large number of cells sometimes occur (Fig. 4). Also by the formation of macro- and microzoogonidia, 2, 4, 8, or 16 of which are formed within the mother-cells.

\section{Cultures.}

In order to obtain, if possible, other stages in the life-history, cultures of the Alga were tried in 0.25 per cent., 0.5 per cent., and 0.75 per cent. Knop's solution. In the stronger solution development was slow, the cells were small, and the culture assumed a brownish tinge. In the 0.25 per cent. solution the Alga reproduced actively by the formation of non-motile gonidia (Fig. 5), and the culture appeared to be a healthy one, although the cells showed some modification in structure. In this solution the cells increased very much in size and gradually became spherical, frequently attaining a diameter of I $4 \mu$ (Fig. 6). The chloroplast, which was crowded with large granules of starch, was no longer small, and in extreme cases appeared to cover the whole interior of the cell-wall. A large pyrenoid with a distinct starch sheath was present in each cell, and was quite visible without treatment with iodine solution. Sometimes two, and rarely three pyrenoids were present (Fig. 7).

This would indicate that the number of pyrenoids present is not constant, but is dependent on nutritive conditions. Further, in the culture in 0.75 per cent. Knop's solution, where development was slow, a pyrenoid could only be detected in a few cases, even after treatment with iodine solution. Thus it would appear that the presence or absence of pyrenoids, or the number present in the chloroplast are characters of no value from a systematic standpoint. ${ }^{1}$

\section{FORMATION OF ZOOGONIDIA.}

At the end of six months, material from the culture in 0.25 per cent. Knop's solution was transferred to a block of sterilized sandstone, standing in a culture dish with a layer of water at the bottom : in order to see whether

\footnotetext{
1 These and many other observations relating to the occurrence of pyrenoids in chloroplasts of the Protococcoideae are entirely opposed to the views advocated by Schmitz, Schmidle (in Ber. Deutsch. Botan. Ges., Bd. xix, I90I, p. 24), and others, that the presence or absence of pyrenoids is sufficiently constant in the chromotophores of the lower types of Green Algae, to be utilized for specific and even generic distinctions.
} 
the Alga would return to its normal state when placed in suitable surroundings. This culture was kept under constant observation. In about ten days zoogonidia began to appear, and in fourteen days zoogonidia were being actively formed, the culture rapidly spreading over the sandstone. ${ }^{1}$

The cells from the old culture continued at first to form non-motile gonidia (Figs. $8 a, 9 a, b$ ). The zoogonidia were formed from these nonmotile gonidia, often while the latter were still within the parent cell, cases being frequent in which some only of the daughter-cells had formed zoogonidia (Figs. $8 \mathrm{~b}, 9 \mathrm{c}$ ). Four, eight, or even sixteen zoogonidia were formed within a single gonidium (Fig. Io). If four only are formed they are $9 \mu$ long by $5 \mu$ broad, while if eight or sixteen are formed they are $7 \mu$ long by $3 \mu$ broad, so that macrozoogonidia and microzoogonidia occur, though the distinction is one of size only, as in other respects they are identical. The zoogonidia vary slightly in shape, being either cylindrical or more or less pointed at one end. They are biciliated, with a parietal chloroplast, which is granular and has a distinct pyrenoid (Fig. I2).

When fully formed they escape from the mother-cell, the process occupying from ten to twenty minutes. Material examined in water at this stage shows at first zoogonidia closely packed within the mother-cell and lying close to the cell-wall. In a few minutes they begin to vibrate slowly, forcing themselves apart and thus distending the cell-wall. As the wall is gradually distended they begin to rotate in different directions, at first slowly, and then with increasing speed, straining the cell-wall more and more until finally it is ruptured, and the zoogonidia escape. These swim actively for some time with the ciliated pole forwards, after which the movements gradually cease and the cilia are withdrawn. On coming to rest, the cell becomes rounded, develops a wall, and at once forms two or four zoogonidia; or it may increase in size and form eight zoogonidia (Fig I3). After repeated generations have been produced in this way, the zoogonidia finally settle down and divide by oblique fission, forming the typical vegetative cells (Fig. I5).

\section{Systematic Position of the Alga.}

The Alga just described belongs without doubt to the family Palmellaceae. The form and size of the cells suggest comparison with those palmellaceous Algae which possess elongated cells.

In the first place it is necessary to consider the Alga described by Harvey, ${ }^{2}$ and subsequently by Cooke, ${ }^{3}$ as Palmella Mooreana. This Alga has occupied a doubtful systematic position since its original description.

1 Klebs, Bedingungen der Fortpflanzung bei einigen Algen und Pilzen, 1896, p. 6o, states that Vaucheria repens produces zoospores when transferred from a solution of inorganic salts to water.

2 Harvey: Manual British Algae, I 85 1 , p. 178.

3 Cooke : Brit. Freshw. Alg., 1882-84, vol. i, p. I4. 
The colonies were described as irregularly globose, of a dark-green colour, about one inch in diameter, and to the naked eye resembling Rivularia. This leads one to the conclusion that Harvey's plant was Aphanothece prasina, a Blue-green Alga which occurs in precisely such colonies as he described. Rabenhorst ${ }^{1}$ was also of the same opinion. Both Hassall, ${ }^{2}$ and De Toni, ${ }^{3}$ have likewise referred Palmella Mooreana to the Blue-green Algae.

Thus the Alga under consideration cannot be referred to Palmella Mooreana, as that Alga is without doubt a blue-green one.

The only other Alga with elongated cells which is definitely known to belong to the Palmellaceae is Dactylothece Braunii, Lagerh. ${ }^{4}$ In this species, however, the cells are symmetrical, and the cell-division is transverse. The mucous envelopes of the cells are also lamellose.

In I90I Schmidle ${ }^{5}$ described the genus Coccomyxa to include an Alga with symmetrical cells, which formed a green gelatinous stratum. The present Alga agrees with this genus in its general habit, its elongated and asymmetrical cells, and in its oblique cell-division. It differs, however, from Schmidle's Coccomyxa dispar in the greater regularity in the form of the cells, and in the presence of pyrenoids.

It would appear that the genus Coccomyxa occupies an intermediate position between the Palmellaceae and the sub-family Selenastreae of the Protococcaceae, and would thus include certain Algae which could not be placed with certainty in either of these groups.

The present Alga can be diagnosed as follows:-Coccomyxa subellipsoidea. Stratum mucous and expanded, of a dark-green colour. Cells commonly obliquely ellipsoid (rarely subspherical), with a single chloroplast in the form of a parietal plate occupying about half the cell-wall and containing one pyrenoid; commonly occurring in pairs after division or scattered in a structureless mucus.

Multiplication by oblique division of the cell. Reproduction by 4 (rarely 8 ) non-motile gonidia, or by the formation of 2,4 , or 8 macrozoogonidia, or 8 or 16 microzoogonidia within a mother-cell. Length of cells 6-10 $\mu$; breadth of cells 4-6 $\mu \mathrm{Hab}$. Widely distributed in British Islands, occurring in subaerial situations as a dark-green stratum on damp rocks and stones.

In the oblique division and in the form of the cell and of the chloroplast, this Alga shows a great resemblance to Oocystis submarina, Lagerh., as described and figured by Wille. ${ }^{6}$

1 Rabenhorst : Flor. Eur. Alg. iii, 1868, p. 34 .

${ }^{2}$ Hassall : Brit. Freshw. Alg., I845, p. 316 , t. 78 , Fig. I.

${ }^{3}$ De Toni : Sylloge Algarum, I889, vol. i, p. 683 .

${ }^{4}$ Lagerheim in Öfvers. af K. Sv. Vet. Akad. Forh., I883, No. 2, t. I, f. 22-4.

${ }^{5}$ Schmidle : loc. cit., p. 20.

${ }^{6}$ Wille in Ber. Deutsch. Botan. Ges., Bd. xxvi, I908, p. 81 2 , t. I5. 
This investigation was carried out under the direction of Dr. G. S. West, to whom I wish to express my sincere thanks for his kindness in supplying me with material, and for many helpful suggestions in the course of the work. I also wish to thank Professor Hillhouse for his kindly advice and for revising the manuscript.

\section{DESCRIPTION OF PLATE XLIII.}

\section{Illustrating Miss Acton's paper on Coccomyxa.}

Figs. I-I $5 \times$ Iooo. $p=$ pyrenoid.

Fig. I. Isolated cells. The shaded portion represents the chloroplast.

Fig. 2. Cells with mucous investment (indicated by dotted line) showing oblique fission.

Fig. 3. Mother-cells containing four non-motile gonidia.

Fig. 4. Subspherical aggregate of cells formed by development of non-motile gonidia in rapid succession; $(a)$ shows an early stage.

Fig. 5. Formation of non-motile gonidia in a culture in 0.25 per cent. Knop's solution.

Fig. 6 . Cells from a culture in $\mathbf{0 . 2 5}$ per cent. Knop's solution, showing increase in size.

Fig. 7. Cell from the same culture with two pyrenoids.

Figs. 8-1 5. Material from a culture on damp sandstone.

Fig. 8. $a$, Formation of four non-motile gonidia ; $b$, Three of these have formed zoogonidia.

Fig. 9. $a, b$, and $c$ show three stages in the formation of zoogonidia.

Fig. 10. Cells containing four, eight, and sixteen zoogonidia respectively.

Fig. II. Fully formed zoogonidia on the point of escaping.

Fig. I2. Zoogonidia. $a, b, c$, are macrozoogonidia; $d$, $e$, microzoogonidia.

Fig. I3. Generation of zoogonidia formed immediately from other zoogonidia without any period of rest.

Fig. 14. (a) zoogonidium with cilia withdrawn; $(b)$ shows a later stage, the pyrenoid has increased in size and the cell has become more rounded; in $(c)$ the pyrenoid has divided.

Fig. I 5. Typical vegetative cell which appeared in the culture after a period of two months. 
Annals of Botany,

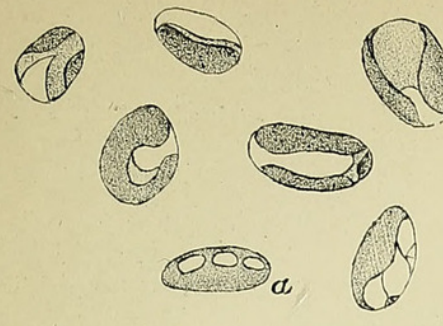

1.

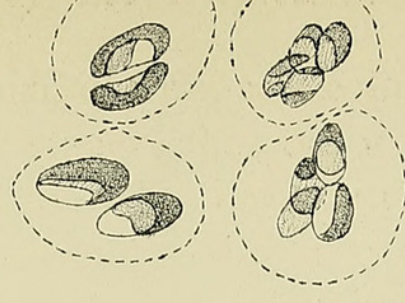

2.

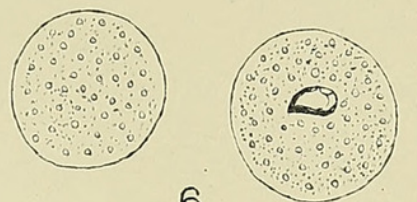

6.

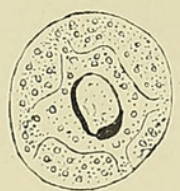

VoZ. XXIII, PL.XIIII.
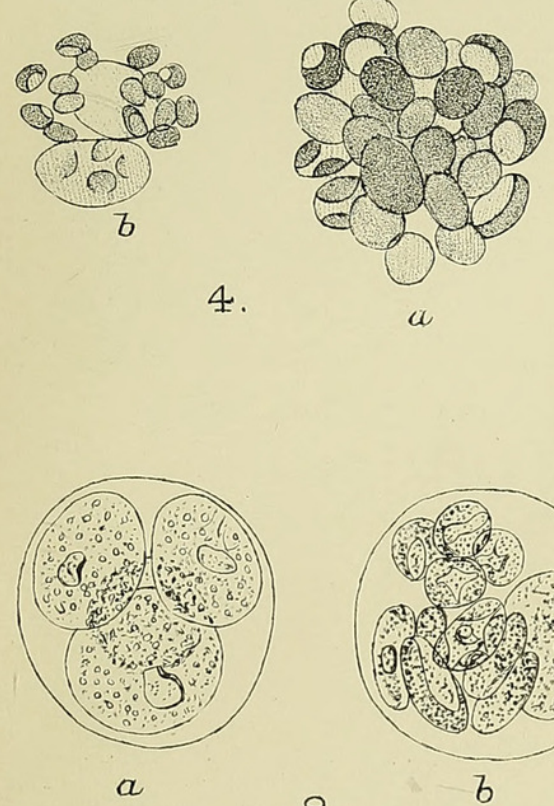

8.
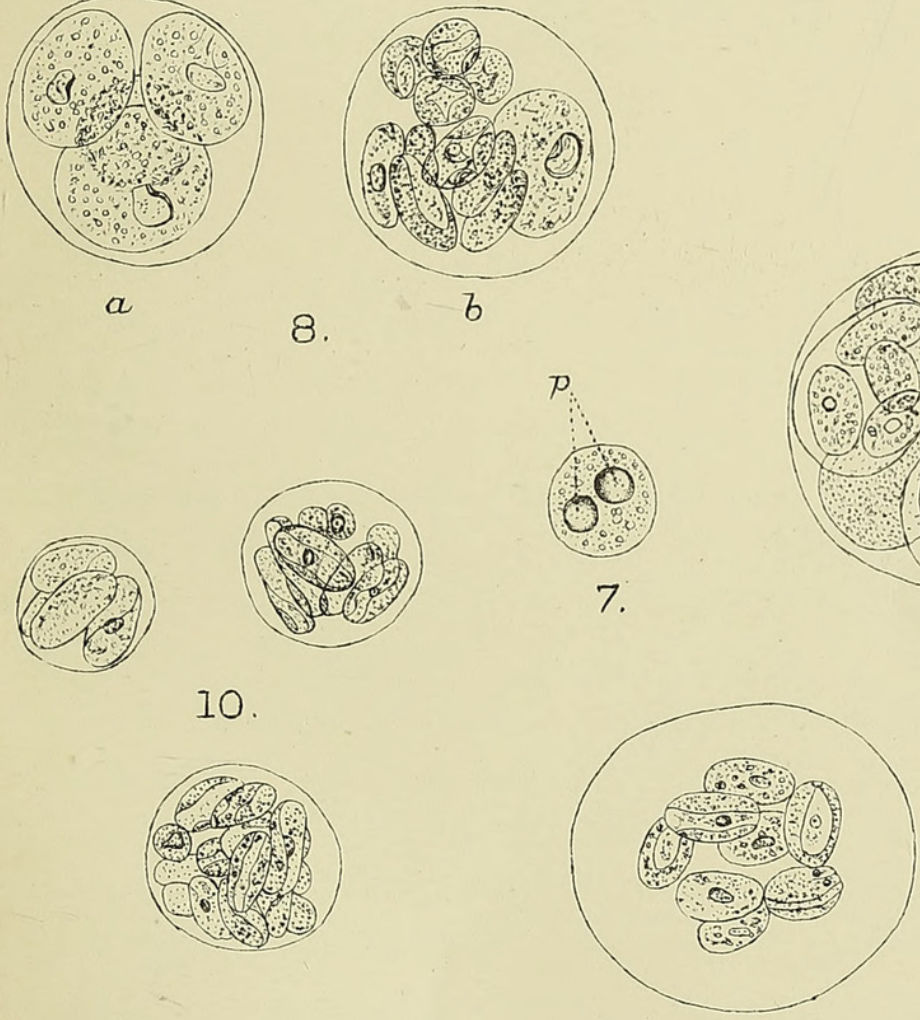

11.
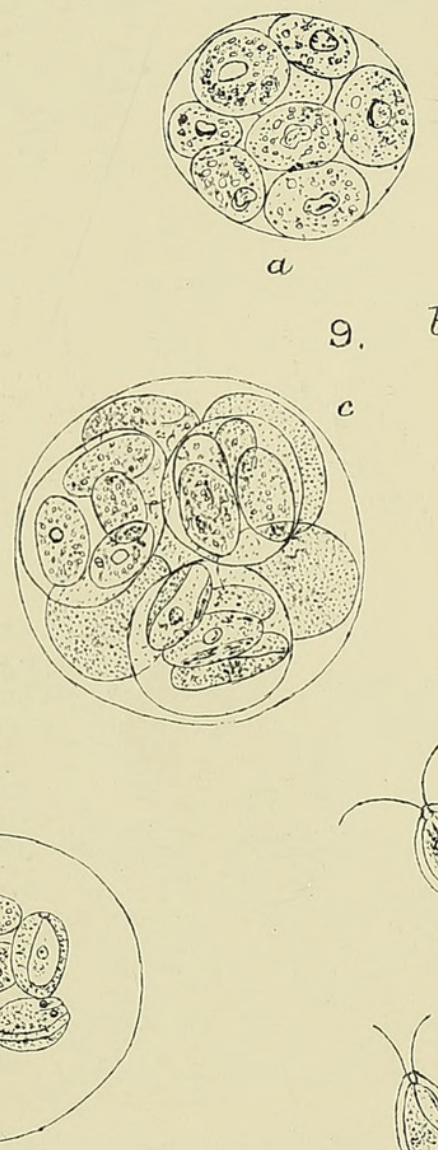

9.

c

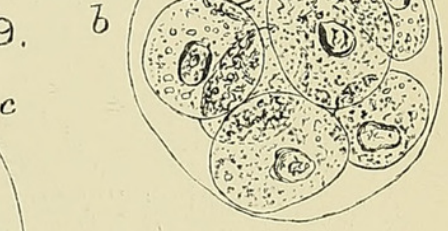

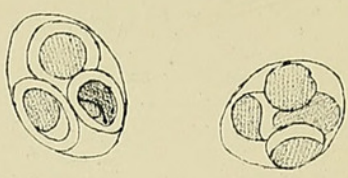

3.

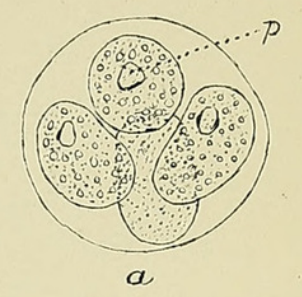

5.

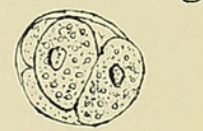

6
(19)

(Q2) 


\section{$2 \mathrm{BHL}$ Biodiversity Heritage Library}

Acton, Elizabeth. 1909. "Coccomyxa subellipsoidea, a new member of the Palmellaceae." Annals of botany 23, 573-577. https://doi.org/10.1093/oxfordjournals.aob.a089239.

View This Item Online: https://www.biodiversitylibrary.org/item/236540

DOI: https://doi.org/10.1093/oxfordjournals.aob.a089239

Permalink: https://www.biodiversitylibrary.org/partpdf/318974

\section{Holding Institution}

Smithsonian Libraries

\section{Sponsored by}

Biodiversity Heritage Library

\section{Copyright \& Reuse}

Copyright Status: Not in copyright. The BHL knows of no copyright restrictions on this item.

This document was created from content at the Biodiversity Heritage Library, the world's largest open access digital library for biodiversity literature and archives. Visit BHL at https://www.biodiversitylibrary.org. 